\title{
DIGITAL CONTACT POTENTIAL PROBE IN STUDYING THE DEFORMATION OF DIELECTRIC MATERIALS
}

\author{
Kanstantsin Pantsialeyeu, Anatoly Zharin, Oleg Gusev, Roman Vorobey, Andrey Tyavlovsky, \\ Konstantin Tyavlovsky, Aliaksandr Svistun \\ Belarusian National Technical University, Instrumentation Engineering Faculty, Minsk, Belarus
}

\begin{abstract}
The paper reviews the results of a study on the surface electrostatic charges of dielectrics obtained using the contact potential difference (CPD) technique. Initially, the CPD technique was only applied to the study of metal and semiconductor surfaces. The conventional CPD measurement technique requires full compensation of the measured potential that, in the case of dielectrics, could reach very high values. Such high potentials are hard to compensate. Therefore, the conventional CPD method is rarely applied in the study of dielectric materials. Some important improvements recently made to the CPD measurement technique removed the need for compensation. The new method, which does not require compensation, has been implemented in the form of a digital Kelvin probe. The paper describes the principles of the non-compensation CPD measurement technique which was developed for mapping the electrostatic surface charge space distribution across a wide range of potential values. The study was performed on polymers such as low-density polyethylene (LDPE) and polytetrafluoroethylene (PTFE).
\end{abstract}

Keywords: surface charge distribution, contact potential difference, Scanning Kelvin Probe, dielectrics materials

\section{MIERNIK CYFROWY DO POMIARÓW KONTAKTOWEJ RÓŻNICY POTENCJALÓW PRZEZNACZONY DO KONTROLI DEFORMACJI MATERIALÓW DIELEKTRYCZNYCH}

\begin{abstract}
Streszczenie. W artykule przedstawiono wyniki badań rozkładu wymuszonych ładunków na powierzchni dielektryków metoda kontaktowej różnicy potencjałów (angl. CPD). Wcześniej metoda CPD byla stosowana jedynie do badań powierzchni metali lub pótprzewodników. Trudności stosowania metody CPD w stosunku do dielektryków wynikają z konieczności calkowitej kompensacji potencjału powierzchniowego, wartość którego może być wysoka. W praktyce taka kompensacja może być utrudniona. W związu z tym metoda CPD nie jest stosowana do badań dielektryków. Ostatnio do techniki pomiarów metoda CPD wprowadzono szereg udoskonalén, które wyeliminowały konieczność całkowitej kompensacji mierzonych wartości. Nowa metoda, która nie wymaga kompensacji, została zrealizowana $w$ postaci cyfrowej sondy Kelvina. W artykule przeanalizowano zasady działania sondy nie wymagającej kompensacji oraz jej zastosowanie do określenia rozkładu ładunku na powierzchni dielektryków w szerokim zakresie wartości potencjału. Badania przeprowadzono na materiałach polimerowych, takich jak polietylen o małej gęstości (LDPE) i politetrafluoroetylen (PTFE).
\end{abstract}

Słowa kluczowe: rozkład ładunku powierzchniowego, kontaktowa różnica potencjałów, skanująca sonda Kelvina, materiały dielektryczne

\section{Introduction}

The generation of static charges in polymer materials under deformation is usually referred to in textbooks as the electroelastic effect [4]. Francis Aston showed interest to this effect in 1901. He used a capacitor made of two brass plates between which rubber was placed. Aston observed a sharp deviation of the quadrant electrometer mirror when the capacitor was loaded. Aston suggested that the resulting charge is associated with the polarization of the dielectric under deformation. Later, Brain, in 1923, explained this effect by piezoelectricity [2].

Significant theoretical interest in the electroelastic effect re-emerged in 1960. The authors of [5] suggested three mechanisms of dielectric (in particular, rubber) charging during the deformation: 1) the appearance of charges of one sign on the specimens; 2) the appearance of charges of different signs on opposite sides; and 3) redistribution of surface charges without the formation of new ones. Subsequent experiments have shown that potentials on the electrometer arise only due to redistribution of charges. Similar experiments on polymers were carried out in 1972 [3], which showed effects similar to piezo effects.

Such studies have not lost their relevance at the present time. First, understanding of polymer charge mechanisms is of significant practical interest, for example, in manufacturing antistatic and insulating materials, fiber production, polymer recycling, etc. [7] Second, there is now a large arsenal of methods for the study of surface electrostatic potentials, and new methods are constantly being developed that can clarify the existing theoretical positions $[7,8,14]$.

Currently, transmission electron microscopy (TEM), an atomic force microscope operating in Kelvin probe mode (KPFM), and electrostatic force microscopy (EFM) as well as a number of electrostatic capacitance probes are used to study the surface charge distribution on dielectrics. A special feature of these methods is the ability to measure only within a small local area of the surface. Surface examination of the specimens as a whole is not provided. The most promising method for non-contact and non-destructive measurement of surface electrostatic potential at micro- and macroscopic scales is the artykuł recenzowany/revised paper
Scanning Kelvin Probe (SKP). Traditionally, this method is used to investigate the surface of metals and semiconductors [11-13, 15]. It determines the work function of the investigated metal surface by measuring the contact potential difference (CPD) between the sample's surface and the reference electrode. One should consider that the conventional CPD probe implements the neutral-zero method of measurements, i.e. it requires full compensation of the measured potential. In the case of dielectrics, this potential could reach very high values. Therefore, the Scanning Kelvin Probe (with micro and macro range resolution) is almost never used for the study of dielectrics materials, however some important improvements were made recently to the CPD measurement technique which eliminated the need for compensation. This technique is implemented in a Digital CPD Probe.

The research work presented in this paper was devoted to experimental studies of the spatial distribution of the surface electrostatic potential on polymers under mechanical stress conditions using the newly developed Digital Kelvin probe.

\section{Measurement technique and research device}

The Kelvin probe technique takes its name from William Thomson (Lord Kelvin), who first introduced it in 1898 [6]. Kelvin used a parallel capacitor of Zinc and Copper plates to explain the Alessandro Volta experiments and to study the charge transfer upon electrical contact. His study implemented a zero CPD measurement method.

In 1932, William Zisman introduced a new method to measure the CPD. He mounted a vibrating reference electrode above a surface of a sample under study [21]. The output voltage varied periodically as the reference electrode vibrated, and the peak-topeak voltage depended on the difference between the CPD and the external bias voltage. Hence the vibrating capacitor that serves as the basis for the conventional CPD probe. This method is completely non-contact and non-destructive for samples [17-20]. In modern measuring systems, the bias voltage is generated automatically by means of special tracking systems [1]. Such tracking systems include phase- or amplitude-sensitive 
detectors (Lock-in) and integrators. The operating principle of the conventional CPD probe is explained in the Fig. 1 [9].

The conventional CPD measurement technique requires full compensation of the measured potential which, in the case of dielectrics, could reach very high values. Therefore, the conventional CPD technique is almost never used for the study of dielectrics materials. Recent improvements to the CPD measurement technique made by the authors eliminate the need for compensation. The non-compensation (or indirect) measurement technique is implemented in the Digital CPD Probe. Fig. 2 shows the structural scheme of the Digital CPD Probe [10].

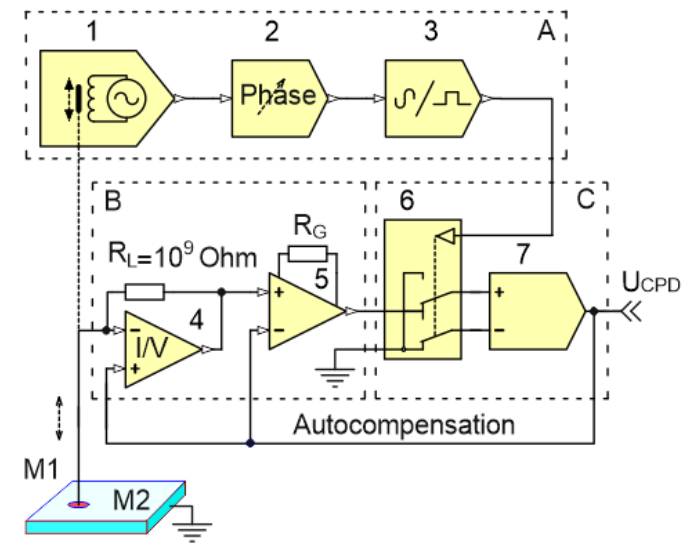

Fig. 1. Basic structure of the conventional CPD Probe: M1, M2 - surfaces of the vibrating reference electrode and sample, respectively; $A$ - modulator ( 1 - vibrator, 2 - phase shifter, 3 -converter); $B$ - preamplifier (4 - current-to-voltage converter; 5 - instrumentation amplifier); $C$ - phase detector-integrator (Lock-In, 6 - switch, 7 - integrator); $U_{C P D}$ - contact potential difference signal [9]

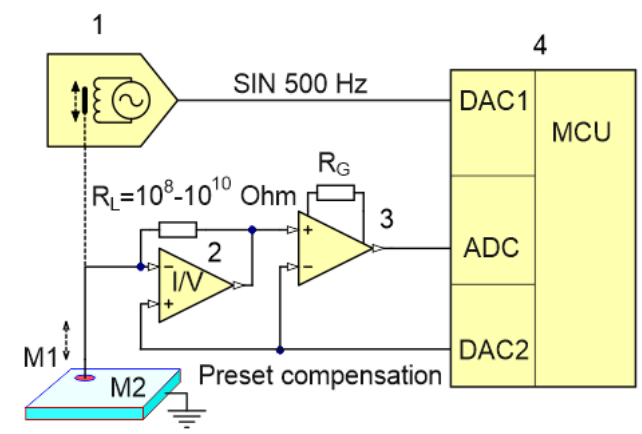

Fig. 2. Basic structure of the Digital CPD Probe: M1 and M2 - surfaces of the vibrating reference electrode and sample, respectively; 1 - modulator consisting of a piezoelectric plate and driver; 2 - current-to-voltage converter; 3 -instrumentation amplifier; 4 -ARM Cortex-M4 microcontroller (MCU) [10]

The Digital CPD Probe is based on an ARM Cortex-M4 microcontroller (MCU). The measuring cycle consists of at least two successive determinations of the output signal amplitude at established values of compensation voltage. The CPD value is determined by interpolating a linear relationship obtained from at least two points (Fig. 3). This approach provides for operation of the Digital CPD Probe in high signal mode with a high signalto-noise ratio.

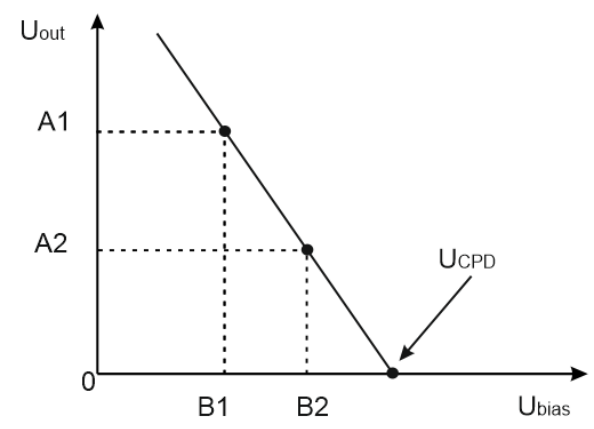

Fig. 3. Principle of Digital CPD Probe basic measuring mode
The MCU generates the compensation voltage and harmonic signal for the probe oscillations via special drivers. This solution synchronizes the oscillations and the readings of the measuring signals at appropriate compensation voltages. the measurement data array is processed using the digital signal processing (DSP) algorithms of the MCU in real-time. The DSP algorithms are mostly used to determine the amplitude of the signal, which in turn is used to calculate the CPD. The additional goal of the DSP is to improve the signal quality (using filters, spectral line detection or fast Fourier transform). In the digital CPD probe, phase detection and integration of the output signal for automatic compensation of the measured value is not necessary. This significantly reduces the measurement time and errors of feedback loop and digital-to-analog conversion [16].

Fig. 4 shows the operating mode of the Digital CPD Probe for electrostatic potential measurement. The fixed compensation voltages (B1 and B2) are selected from outside the range of possible CPD values. This allows for CPD measurements over a wide range, up to hundreds of volts. In this case, the CPU generates compensation potentials which do not exceed \pm 10 Volts. The CPD value $\left(\mathrm{U}_{\mathrm{CPD}}\right)$ is determined by formula (1):

$$
U_{C P D}=-\frac{B_{1} \cdot A_{2}+B_{2} \cdot A_{1}}{A_{1}-A_{2}}
$$

where $A_{1}$ and $A_{2}$ - amplitude of the alternating signal at the corresponding preset compensation potentials $B_{1}$ and $B_{2}$.

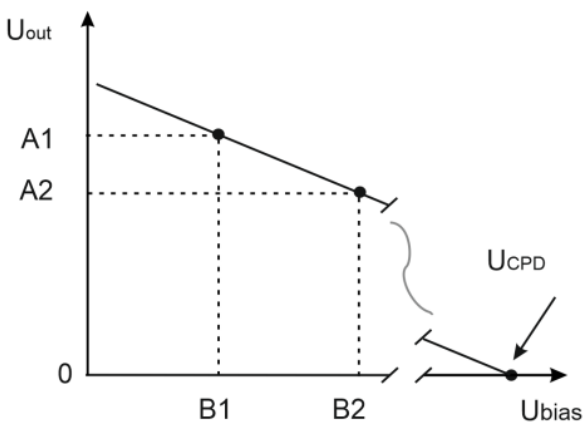

Fig. 4. Measuring operation mode of the Digital CPD Probe for high electrostatic potentials (up to several hundred volts)

The study of the spatial distribution of the surface electrostatic potential was carried out with a developed measuring system that implements a Scanning Kelvin Probe. The main technical characteristics of the developed Scanning system are given in Table 1 .

Table 1. Main technical characteristics of the Scanning system

\begin{tabular}{|c|c|}
\hline Parameters & Characteristics \\
\hline Main controlled parameter & Electrostatic potential \\
\hline Electrostatic potential probe & $\begin{array}{c}\text { Digital Kelvin-Zisman contact } \\
\text { potential difference probe }\end{array}$ \\
\hline $\begin{array}{c}\text { Diameter of the electrostatic } \\
\text { potential probe, } m \mathrm{~m}\end{array}$ & 1 \\
\hline $\begin{array}{c}\text { Error of surface potential } \\
\text { measurement, } \mathrm{mV}\end{array}$ & 32 \\
\hline Positioning system & \pm 5 \\
\hline Positioning accuracy, $\mu \mathrm{m}$ & 10 \\
\hline Spatial resolution, $\mu \mathrm{m}$ & $200 \times 200$ \\
\hline Scanning area, $\mathrm{mm}$ & 100 to 100,000 \\
\hline Mapping points & \\
\hline
\end{tabular}

\section{Results and discussion}

The response of the surface electrostatic potential of polymer materials to external mechanical action was found earlier in [8]. This study used matrix high-pressure polyethylene (LDPE) 12203250 grade as samples. The registered deviations of the surface electrostatic potential (similar to Fig. 5b) were caused by the action of a vacuum clamp that was used to fix the specimens on the object table of the scanning system. We could not estimate the pressure with which the vacuum clamp acts on the specimens. This pressure was not quantitatively estimated as it was not significant from the point of view of any mechanical 
properties of the material, but it turned to be significant for its charge distribution. To assess this, additional measurements were taken.

From Fig. 5, one can see that the electrostatic potential is distributed relatively uniformly over the surface when the vacuum clamp is turned off. After turning on the clamp, we observe a redistribution of the surface electrostatic potential in the clamping area. Further, we see the process of relaxation and a decrease in residual stresses (the clamp off). The homogeneity of the electrostatic potential distribution was completely restored after 14 hours.

Measurements performed on the composite polymers (LDPE $+6 \%$ carbon nanomaterial and LDPE $+3 \%$ nano-sized silica) showed similar results. But it was not possible to register any changes in the distribution of the surface electrostatic potential on samples with a combined filler (LDPE + carbon nanotubes + carbon nanomaterial + nano-sized silica with different mass ratios). The obtained results allow for some conclusions concerning the effect of the combined filler on the mechanical properties of the material. This effect correlates well with a known statement that carbon-filled composite materials or materials with carbon nanotubes have a high resistance to static or cyclic mechanical stress.

To evaluate the capabilities of the Digital CPD probe in studying the stress-strain state of dielectric materials, a system for mechanical stretching of specimens was built. The system was integrated with a scanning system for electrostatic potentials. This made it possible to obtain the distribution of the electrostatic potential maps in the course of loading.
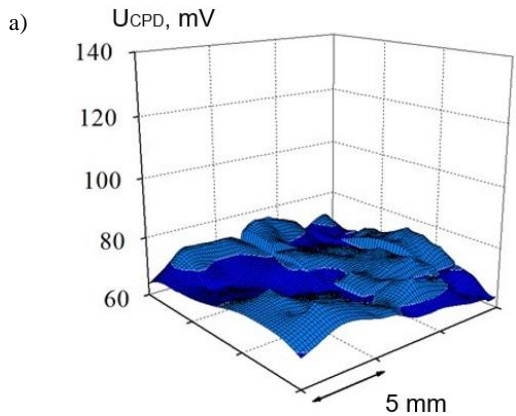

b)
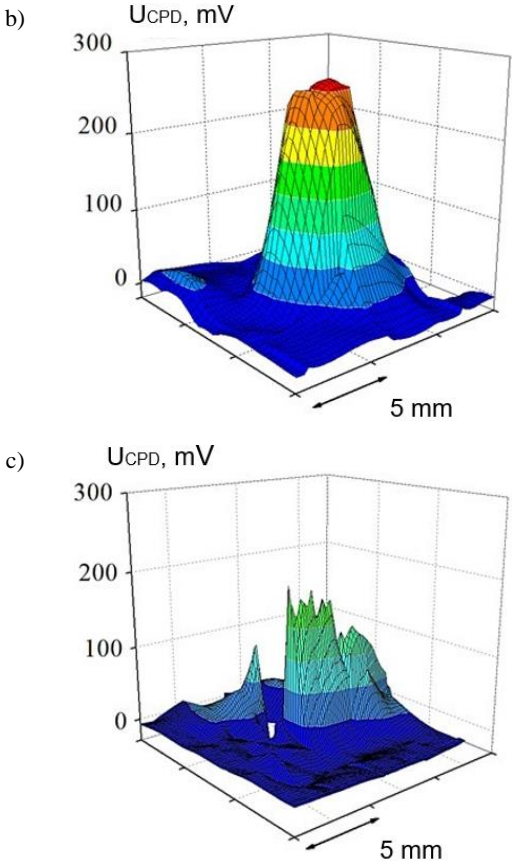

Fig. 5. Electrostatic potential distribution maps of low-density polyethylene (LDPE) with a short-term application of mechanical load: a) before loading; b) after loading. c) in the course of relaxation (up to 4 hours after loading
Fig. 6 shows the surface electrostatic potential distribution maps of samples after the mechanical tensile load. The samples under study were made of Polytetrafluoroethylene (PTFE) F4. These samples were loaded with a $1 \mathrm{kgf}$ step and scanned for the surface electrostatic potential. The loading led to electrostatic potential heterogeneity with sharp extremes propagating from the center of the deformed area of the material outwards. This area and the surface relative potential increase with increasing load. Under further loading, the potential reaches saturation.

a)

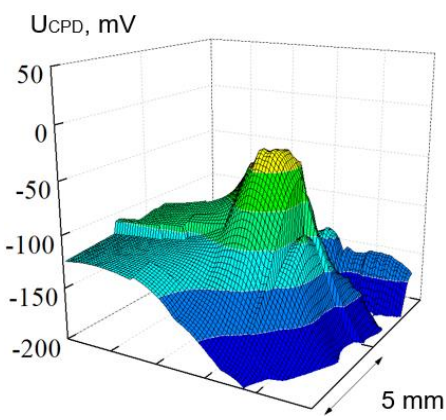

b)

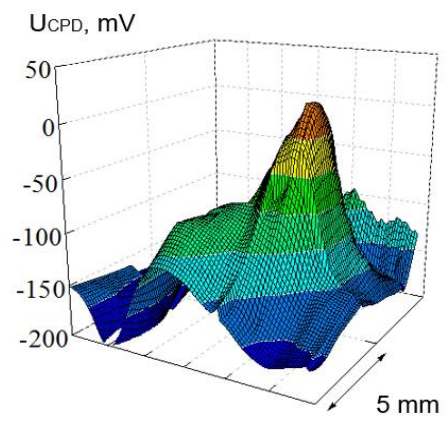

c)

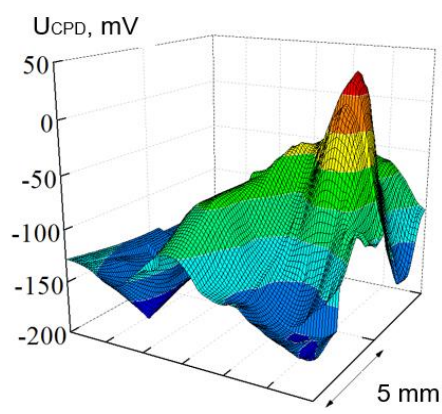

Fig. 6. Electrostatic potential distribution maps of low-density polyethylene (LDPE) with a short-term application of mechanical load: a) before loading; b) after loading; c) in the course of relaxation (up to 4 hours after loading)

\section{Conclusion}

The paper describes the principle of the Non-compensation (or indirect) CPD measurement technique, which was developed for mapping the spatial distribution of electrostatic surface charge in a wide range of permissible values. The indirect measurement technique is implemented in the Digital CPD Probe. The obtained results include the identification of promising opportunities for the CPD technique, and in particular, application of the Digital CPD Probe for studying charged dielectrics. In scanning mode, this technique can be applied both to study the surface electrostatic potential (charge) distribution and to study its redistribution from the load, including in vitro study. The research shows that the surface electrostatic potential for some dielectric materials and polymer composites is a highly sensitive parameter to changes in the stress-strain state. Therefore, the considered measuring technique can be applied to the non-contact and non-destructive detection of deformation dispositions, control of residual stresses, relaxation and other parameters of the dielectric materials in the stress-strain state, and also to the study of their mechanisms. 


\section{References}

[1] Baumgartner H.: New method for the distance control of a scanning Kelvin microscope. Measurement science \& technology 2(3), 1992, 237-238

[2] Brain K. R.: Investigations of piezo-electric effects with dielectrics. Proceedings of the Physical Society of London 36(1), 1923

[3] Broadhurst M. G., Malmberg C. G., Mopsik F. I., Harris W. P.: Piezo- and pyroelectricity in polymer electrets. Conference on Electrical Insulation \& Dielectric Phenomena. Annual Report, 1972 [http://doi.org/10.1109/ceidp.1972.7734193].

[4] Davies D. K.: Charge generation on dielectric surfaces. Journal of Physics D: Applied Physics 2(11), 1969, 1533-1537 [http://doi.org/10.1088/00223727/2/11/307].

[5] Dogadkin B. A., Gul V. E., Morozova N. A.: The Effect of Electric Charges Formed during Repeated Deformations on the Fatigue Resistance of Vulcanizates. Rubber Chemistry and Technology 33(4), 1960 [http://doi.org/10.5254/1.3542237].

[6] Kelvin L.: Contact electricity of metals. Philosophical Magazine (series 5) 46(278), 1898, 82-120 [http://doi.org/10.1080/14786449808621172].

[7] Lei Zhang, Zhiwei Chen, Jiale Mao, Shuang Wang, Yiting Zheng: Quantitative evaluation of inclusion homogeneity in composites and the applications (Review Article). Journal of Materials Research and Technology 9(3), 2020 [http://doi.org/10.1016/j.jmrt.2020.01.067].

[8] Pantsialeyeu K. U., Krautsevich A. U., Rovba I. A., Lysenko V. I., Vorobey R. I., Gusev O. K., Zharin A. L.: Analysis of the electrophysical and photoelectric properties of nanocomposite polymers by the modified Kelvin probe. Devices and Methods of Measurements 8(4), 2017, 386-397 (in russian) [http://doi.org/10.21122/2220-9506-2017-8-4-55-62].

[9] Pantsialeyeu K., Mikitsevich U., Zharin A.: Design of the contact potentials difference probes. Devices and Methods of Measurements 7(1), 2016, 7-15 (in russian) [http://doi.org/10.21122/2220-9506-2016-7-1-7-15].

[10] Pantsialeyeu K., Svistun A., Tyavlovsky A., Zharin A.: Digital contact potential difference probe. Devices and Methods of Measurements 7(2), 2016, 136-144 (in russian) [http://doi.org/10.21122/2220-9506-2016-7-2-136-144].

[11] Pantsialeyeu K., Svistun A., Zharin A.: Methods for local changes in the plastic deformation diagnostics on the work function. Devices and Methods of Measurements 10(1), 2015, 56-63.

[12] Pilipenko V., Solodukha V., Zharin A., Gusev O., Vorobey R., Pantsialeyeu K., Tyavlovsky A., Tyavlovsky K., Bondariev V.: Influence of rapid thermal treatment of initial silicon wafers on the electrophysical properties of silicon dioxide obtained by pyrogenous oxidation. High Temperature Material Processes: An International Quarterly of High-Technology Plasma Processes 23(3), 2019, 283-290 [http://doi.org/10.1615/HighTempMatProc.2019031122].

[13] Qin W. G., Shaw D. A.: Theoretical model on surface electronic behaviour: strain effect. Phys. B: Condensed Matter 6(16), 2009, 2247-2250.

[14] Sviridenok A., Zharin A., Krautsevich A., Tyavlovsky A.: The effect of highdispersion fillers on adhesive and frictional properties of ethylene-vinyl acetate copolymer. Journal of Friction and Wear 35, 2014, 255-262.

[15] Sykes J. M., Doherty M.: Interpretation of Scanning Kelvin Probe potential maps for coated steel using semi-quantitative current density maps. Corrosion Science 50, 2008, 2773-2778 [http://doi.org/10.1016/j.corsci.2008.07.023].

[16] Tyavlovsky A. K., Zharin A. L., Gusev O. K., Kierczynski K.: Kelvin Probe error compensation based on harmonic analysis of measurement signal. Przeglad Elektrotechniczny 90, 2014, 251-254.

[17] Vorobey R. I. Gusev O. K. Tyavlovsky A. K., Svistun A. I., Shadurskaja L., Yarzhembiyskaja N., Kerczynski K.: Controlling the characteristics of photovoltaic cell based on their own semiconductors. Przeglad Elektrotechniczny 91(8), 2015, 81-85 [http://doi.org/10.15199/48.2015.08.21].

[18] Wicinski M., Burgstaller W., Hassel A. W.: Lateral resolution in scanning Kelvin probe microscopy. Corrosion Science 104, 2016, 1-8 [http://doi.org/10.1016/j.corsci.2015.09.008].

[19] Zharin A., Pantsialeyeu K., Kierczyński K.: Charge sensitive techniques in control of the homogeneity of optical metallic surfaces. Przegląd Elektrotechniczny 92(8), 2016, 190-193 [http://doi.org/10.15199/48.2016.08.52]

[20] Zharin A., Pantsialeyeu K., Opielak M., Rogalski P.: Charge sensitive techniques in tribology studies. Przeglad Elektrotechniczny 92(11), 2016, 239-243 [http://doi.org/10.15199/ 48.2016.11.58].

[21] Zisman W.: A new method of measuring contact potential differences in metals. Review of Scientific Instruments 3(7), 1932, 367-370 [http://doi.org/10.1063/1.1748947].

\section{Ph.D. Kanstantsin Pantsialeyeu}

e-mail: k.pantsialeyeu@bntu.by

Ph.D., Associate Professor of the Department of Information Measuring Devices and Technologies of Belarusian National Technical University. Fields of research: Charge sensitive methods for detecting mechanical effects on the surface of friction materials.
Prof. Anatoly Zharin

e-mail: zharin@bntu.by

Doctor of technical sciences, professor of the Department of Information Measuring Devices and Technologies of Belarusian National Technical University. Fields of research: modern electronics and computer technology; experimental physics; solid state physics; tribology; composite materials.

http://orcid.org/0000-0001-7213-4532

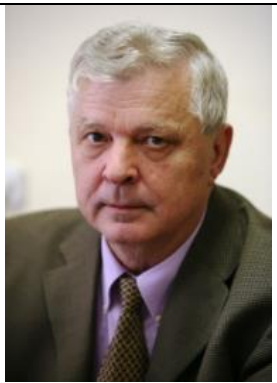

\section{Prof. Oleg Gusev}

e-mail: gusev@bntu.by

Doctor of technical sciences, Vice-Rector for Academic Activity of Belarusian National Technical University, professor of the Department of Information Measuring Devices and Technologies of Belarusian National Technical University. Fields of research: modern electronics and computer technology; experimental physics; solid state physics; semiconductor materials; optoelectronics.

http://orcid.org/0000-0001-5180-1121

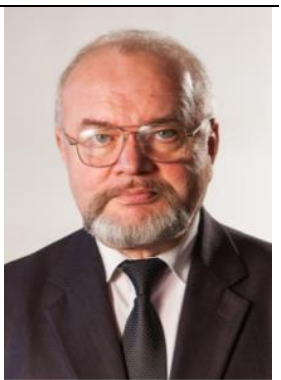

Ph.D. Roman Vorobey

e-mail: vorobey@bntu.by

Ph.D., Associate Professor, Head of the Department of Information Measuring Devices and Technologies of Belarusian National Technical University. Fields of research: instrumentation engineering; metrology and information measuring devices and systems; semiconductor materials; optoelectronics.

http://orcid.org/0000-0003-2851-6108

Ph.D. Andrey Tyavlovsky

Ph.D., Associate Professor of the Department of Information Measuring Devices and Technologies of Belarusian National Technical University. Fields of research: Probe electrometry and research parameters of precision surfaces based on the KelvinZisman method.

http://orcid.org/0000-0003-2579-1016

Ph.D. Konstantin Tyavlovsky

e-mail: ktyavlovsky@bntu.by

Ph.D., Associate Professor of the Department of Information Measuring Devices and Technologies of Belarusian National Technical University. Fields of research: Probe electrometry and research parameters of precision surfaces based on the KelvinZisman method; semiconductor materials; optoelectronics

http://orcid.org/0000-0001-8020-0165
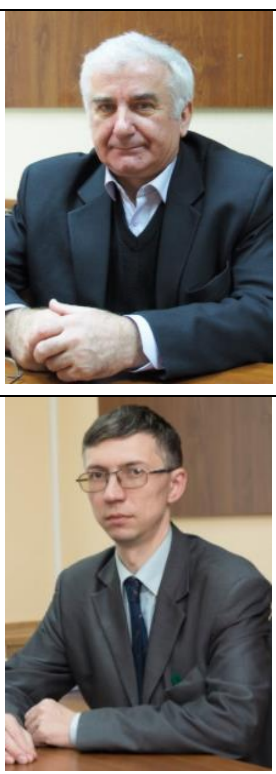

e-mail: aisvistun@bntu.by

Ph.D., Associate Professor, Head of the Instrumentation Engineering faculty of Belarusian National Technical University. Fields of research: Probe electrometry; metrological provision of multiparameter measurement of optical radiation.

http://orcid.org/0000-0002-9593-8880

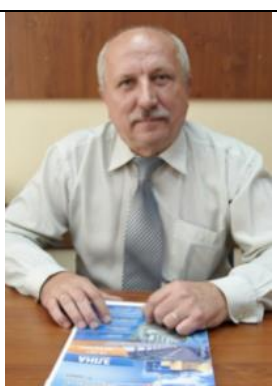

otrzymano/received: 27.10 .2020

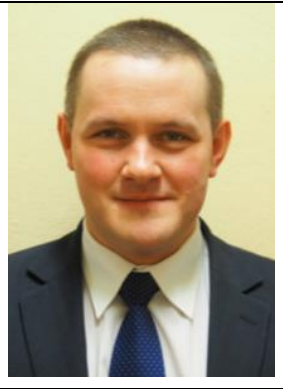

przyjęto do druku/accepted: 10.12 .2020 